\title{
Regional Inequalities in the Visegrad Group Countries, Serbia and Croatia
}

\author{
Radoslav Klamár ${ }^{A^{*}}$, Ján KozoňA, Monika IvanováA \\ Received: April 07, 2020 | Revised: May 26, 2020 | Accepted: May 27, 2020 \\ doi: 10.5937/gp24-26038
}

\begin{abstract}
The paper discusses the evaluation of regional inequalities in the $V_{4}$ countries, Serbia and Croatia. The gross birth rate, the unemployment rate, the average monthly gross earnings, the gross domestic product per capita in purchasing power parity and dwellings completed per 1000 inhabitants were selected as a set of evaluation indicators and, to determine the level of regional inequalities the Gini Coefficient and the Coefficient of Variation in two variants were used - in all the counties as well as after excluding the capital cities. The integrated indicator of socio-economic status based on the above-specified indicators revealed the prevailing dichotomy of the prosperous west vs. the problematic east in the majority of the countries, the most significantly in Slovakia. This country together with Hungary recorded (mainly thanks to the significant effect of the capital city) the most significant inequalities while the less significant ones were in the Czech Republic, Serbia and Croatia. The strong effect caused by the capital city was confirmed almost in all the countries except for Poland. The level of the dependence between the socio-economic status of the countries and the level of their inequalities was confirmed only partially.
\end{abstract}

Keywords: Croatia; regional inequalities; Serbia; socio-economic status; Visegrad Group countries; west-east dichotomy

\section{Introduction}

A growing spatial inequality is the chief present-day problem of socio-economic development from the geographic and economic point of view. In the recent years, disparities have become a great point of interest of geographical and economic sciences, as manifested by the fast-growing number of publications on the subject (Czyż \& Hauke, 2011).

The seriousness of the matter is proven not only by the widespread academic discussion, but it is also perceived by the general public and, its intensification is looked at as something negative. This view of regional inequalities is one of the main reasons for the research.

This paper focuses on the evaluation of regional inequalities in six selected countries. The first four ones
- the Czech Republic, Poland, Slovakia and Hungary have been closely cooperating for nearly 30 years as the Visegrad Group countries (abbreviated to the $\mathrm{V}_{4}$ countries). Since 2004, they have been the EU members. The remaining two countries, Serbia and Croatia, were a part of Yugoslavia in the 1990s. Croatia became the EU Member State in 2013 and Serbia is a candidate country. The development trajectories of the evaluated countries vary, however, each of them went or is going through an intensive transformation process that commenced in the 1990 os. This process revealed the real economic performance of the countries and their regions that manifested itself as various levels of forming regional inequalities.

\footnotetext{
A Department of Geography and Applied Geoinformatics, Faculty of Humanities and Natural Science, University of Presov, 17. novembra 1, 08001 Prešov, Slovakia, radoslav.klamar@unipo.sk, jan.kozon@smail.unipo.sk, monika.ivanova@unipo.sk

* Corresponding author: Radoslav Klamar; radoslav.klamar@unipo.sk
} 


\section{Theoretical Background}

In the broadest sense, disparities are understood as a divergence or inequality of characters, phenomena or processes, the identification and comparison of which make some rational sense (cognitive, psychological, social, economic, political) (Kutscherauer et al., 2010). It is an inequality or a divergence caused by essential tendencies in the development of the society which is a significant level of its variability resulting in uneven development (Hučka et al., 2008).

There are two essential approaches to their evaluation, a positive and a negative one (Majerová, 2012). Kutcherauer and Hučka (2011) designate the negative approach as a 'disparite approach' that sees regional inequalities as weaknesses. It is reckoned as a dominant approach while numerous authors recommend introducing measures to stop their increase (Gurgul \& Lach, 2011), because differences in regional development are not favourable for the socio-economic development of the whole country, and what is more, they are damaging (Czyż \& Hauke, 2011). On the other hand, excessive endeavours to reduce inequalities may lead to overall stagnation of socio-economic development of the whole country (Blažek \& Csank, 2007).

Regional inequalities started to fully manifest themselves in the countries of Central and Eastern Europe ('CEE') because of political and economic changes in the early 1990s. As quoted by Lackenbauer (2004), until then, the countries have lost out on at least half a century of 'normal' economic development. The nature of their growth caused serious structural deformations in their economies that made them highly ineffective when compared to Western Europe. The transformation from centrally-planned economy to western-style democracy and market economy caused the dramatic development of changes in their economic, social, ecologic and spatial development (Miljanović et al., 2010).

At the beginning of the transformation process, the countries shared remarkably similar low level of inequality. As the time went, the situation dramatically changed and inequality diverged considerably (Ivančev et al., 2010).

According to Monastiriotis (2013), the changes in the early 1990s encouraged the polarization trend when central places (mainly capitals and their hinterlands) were growing faster, benefiting from the concentration of financial and political capital, a higher share of FDI and sufficient qualified workforce as well as the basic trend of East-West dichotomy supported by differences from the point of proximity to the 'Western core' (the so-called blue banana).
In this context, Lackenbauer (2006) points out to two types of winners, represented by metropolitan regions (mainly capitals) and the regions neighbouring the old EU Member States, and two types of losers, that are rural and declining industrial areas as well as regions in Eastern peripheries.

Similarly, Kisiała and Suszyńska (2017) drew attention to the trend of increased interregional inequalities in initial phases of national economy growth and consequent interregional convergence. According to them, this mutual dependence may be explained by the fact that, in insufficiently developed countries, there were few regions that would be proud of having attributes of so-called 'growth poles'. In these areas, it was possible to monitor growing productivity and increased pace of growth compared to the other regions in the country thanks to a high concentration of production factors, better technical equipment and workforce offer. These growth poles were the metropolitan areas in the majority of developing countries, often also the regions of their capitals. According to Domański (2011), these areas are the most obvious winners of the post-socialist transformation. They benefit from the development of advanced producer services and the location of new manufacturing plants, being the most attractive place for both, foreign investments and the growth of small- and medium-sized indigenous firms. Partners for cooperation can be more easily found here, so large investors are more likely to become regionally embedded.

The initial divergence caused by faster growth of economically strongest regions manifested itself first as spatial polarization. Along with gradual growth of economies in transforming countries, the processes of spreading growth impulses to other regions should lead to spatial balance and the elimination of inequalities (Bogumił, 2009; Gurgul \& Lach, 2011; Smętkowski, 2014; Kisiała \& Suszyńska, 2017; Fecková Škrabuláková et al., 2019).

Transformation steps, the gradual progress of CEE countries and their approach to the economic levels of the former EU-15 countries in the first decennium of the 21st century remarkably accelerated due to their accession to the EU. Both, direct and indirect impacts of their accession to the EU, as well as favourable world economic environment until the economic crisis in 2008 are considered by Smętkowski (2014) as the main accelerators of their development.

The financial and economic crisis slowed development down in almost all the countries and the first indications of a return to economic growth were observed in 2012 and 2013. As referred by Klamár et 
al. (2019b), in Slovakia, the years of economic crisis meant the stagnation or the decrease of inequalities and since 2013 their gradual increase has been observed.

\section{Methodology}

In assessing regional inequalities, it is necessary to solve several methodological problems. It is necessary to define the observational level of the evaluated territorial units, determine the choice of adequate indicators for the assessment as well as to select the appropriate statistical tools for their measurement (Matlovič \& Matlovičová, 2005, 2011).

When selecting appropriate hierarchical level of compared territorial units, the lower level of the observational unit, the more growing problem of the availability and relevance of observed data and time series (Klamár, 2016). In international comparisons, mainly levels NUTS 2 and NUTS 3 are used. While Eurostat evaluates the majority of indicators on level NUTS 2, level NUTS 3 describes the monitored problem in details; however, less statistical data are available. Also, this paper uses level NUTS 3, and in the case of the Czech Republic there are 14 counties, in Slovakia 8, in Hungary 20, in Poland 73, in Croatia 21 and in Serbia 30 (5 counties were without input data), that were jointly marked as counties for sake of the better comparison (in the Czech Republic and Slovakia they are called 'kraje', in Poland - 'podregiony', in Hungary - 'megyék', in Serbia - 'okruzi', in Croatia 'županije').

Another step was to choose evaluation indicators and that was alike influenced by data availability. Five indicators were chosen for the evaluation purposes, namely the gross domestic product per capita in purchasing power parity (PPP) (adjusted by the price level indices in the particular country), the gross birth rate (abbreviated to: birth rate), the unemployment rate, the average monthly gross earnings (abbreviated to: monthly earnings) and dwellings completed per 1000 inhabitants (abbreviated to: dwellings completed.) These indicators were for 2018 (only GDP per capita in PPP - 2016 and monthly earnings in Croatia - 2017) and had the same weight in evaluation. The selection of the indicators was conditioned by already mentioned availability of data from the evaluated counties on the NUTS 3 level (counties) as well as by their informative capability in relation to economic, social and demographic development. The most crucial and complex indicator is the economic indicator the gross domestic product per capita that characterizes the economic prosperity or the underdevelopment of a region from the point of its production potential. It is suitable to evaluate the maturity of economics and the intensity of regional develop- ment. Another indicator is the average monthly gross earnings reflecting the disposable resources to satisfy the basic life needs and to assure consumer standards. The economic indicator with a remarkable social subtext is the unemployment rate representing the share of disposable registered number of the unemployed to the number of economically active inhabitants. The gross birth rate is an important demographic indicator that shows the reproduction vitality and the perspective of individual regions. Quality and available housing shown by the dwellings completed per 1000 inhabitants is an important factor influencing workforce mobility.

For purposes comparison, the monthly earnings in the Czech Republic, Hungary, Poland, Croatia and Serbia were converted to euro using the average annual exchange rate in the monitored period. The issue of the selection of indicators of regional inequalities is discussed in detail for example in the work of Ancuţa (2012).

In order to make the first evaluation of indicators we used the integrated indicator - socio-economic status (e.g. in the work of Klamár et. al., 2019a), the construction of which came out of the point method. The basis for the comparison of each indicator was its highest level achieved in any of the counties. The highest value was 100 points, this was the basic quantity when compared to other counties, and it was used for comparisons of values achieved in every indicator in other counties. The value per each county was the result of addition of values per individual indicators (max. 500 p.). In this part of the analysis, we defined the first hypothesis Hi in which we presumed that the counties in the western parts of the evaluated countries have a higher level of socio-economic status than the counties in the eastern parts. On the map of socioeconomic status, we marked the numbers of the counties in the highest quartile with a circle and in the lowest one with a square (Fig. 1 in the annex).

The next step was to choose statistical tools to measure inequalities. There are more indexes which can be used, e.g. the coefficient of variation, the Gini coefficient, the Theil index, the Hoover index, the Atkinson index, the real convergence method, etc. The most frequently used are the coefficient of variation and the Gini coefficient that are used individually or jointly by numerous authors and that were also used in this paper (coefficient of variation - CV, Gini coefficient IG). The coefficient of variation is a relative measure of 
dispersion derived from the standard deviation $\sigma$ (the ratio of the standard deviation and the mean)

$$
C V=\frac{\sigma}{\bar{x}}=\frac{\sqrt{\frac{\sum_{i=1}^{n}\left(x_{i}-\bar{x}\right)^{2}}{n}}}{\bar{x}}
$$

where $n$ is the total number of territorial units, $x_{i}$ is the value of the indicator $\mathrm{x}$ in territorial unit $i$ and is the arithmetic mean of the indicator $x$.

An advantage of the coefficient of variation is the fact that it is not dependent on the measured values of the input indicators. It enables mutual comparison of variability of variable and different values (Michálek, 2012). The drawback of the coefficient of variation is that the result value depends of mean and causes the loss of sensitiveness to extreme values (Rusnák, 2012).

The second statistical measure was the Gini coefficient, which originated as a tool to measure income inequality. It ranges between o (absolute equality) to 1 (absolute inequality).

$$
I G=\frac{1}{2 n^{2} \cdot \bar{x}} \cdot \sum_{i=1}^{n} \sum_{j=1}^{n}\left(x_{i}-x_{j}\right)
$$

where $n$ is the total number of territorial units, $x_{i}$ is the value of the indicator in the i-territorial unit, $x_{j}$ is the value of the indicator in the $j$-territorial unit and is the arithmetic mean of the indicator $x$.

An advantage of the Gini coefficient is its independence of mean and rather low sensitivity to extreme values (Cowell \& Flachaire, 2007 In Nosek \& Netrdová, 2010). Its only drawback is that it does not comply with the decomposability condition i.e. the calculated value of the Gini coefficient in a country as a whole is different from the total value of the Gini coefficients calculated per individual counties in the country.

In this part, we define hypothesis $\mathbf{H} \mathbf{2}$, in which we presume the lowest level of inequalities in the countries in the gross birth rate as the only non-economic indicator and hypothesis $\mathbf{H}_{3}$, in which we presume that the level of regional inequalities is lower in terms of average monthly gross earnings in the evaluated countries than the unemployment rate, just like it was pointed out by Puljiz and Maleković (2007) in Croatia.

Apart from the analysis carried out as described above, we also evaluated regional inequalities using both said coefficients from the point of importance of their capitals (Lackenbauer, 2006; Bogumił, 2009; Monastiriotis, 2013; Smętkowski, 2014; Illieva, 2015 etc. pointed out to the importance of their influence to regional inequalities in the CEE countries). That is why we have excluded the counties of the capital cities from the evaluation so that it was possible to define the level of inequalities without their impact. We have made hypothesis $\mathbf{H}_{4}$, in which we presume a significant decrease of regional inequalities in the observed countries after the exclusion of their capital cities.

As the last step, we evaluated the level of dependence between the socio-economic status of the evaluated countries and the level of their inequalities. The socioeconomic status of the countries was evaluated using the set of the same five indicators (however, on the national level in this case), while applying the point method again. The socio-economic status was consequently correlated with the level of regional inequalities in two variants all the counties and without their capitals. To define dependence, we used the regression and the correlation analysis where the socio-economic status of a country was an independent variable and the size of regional inequalities (in both variants) was a dependent variable. The suitability of the linear regression model was verified by ANOVA (Analysis of Variance) in the program STATISTICA, where the null hypothesis Ho was tested: 'The model is not appropriate for use. The F value represented test characteristics, whose significance was given by the p-value indicating the smallest possible level of significance for rejection of the null hypothesis. When the p-value was $\leq 0.05$, the null hypothesis was rejected at a given significance level $\alpha=0.05$. Regarding the fact that strict criteria to classify the values of the Pearson correlation coefficient into separate groups according to the level of dependence intensity do not exist, we relied on established practice and the data character (e.g. works by Gregorová \& Fillová, 2004; Chajdiak, 2009). The Pearson correlation coefficient $\mathrm{R}$ was the rate to appraise the power of linear dependence, the absolute values of which approaching to 1 indicated the growth of power of the relation between country's socio-economic status and the size of its regional inequalities. To the contrary, the more $\mathrm{R}$-values approached to o, the more grew the independence between the evaluated indicators.

Despite the fact that the Pearson correlation coefficient is suitable and a frequently used coefficient to express the intensity of linear dependence, we miss similar indexes to express the strength of dependence in non-linear regression models (also regarding the intricacy of the regression function). The Pearson correlation coefficient to the power of two makes the coefficient of determination. The coefficient of determination $R^{2}$ expressed as a percentage of the variation of the dependent variable explained by the variation in the independent variable. At this stage, we defined hypothesis $\mathbf{H}_{5}$ saying that the level of regional inequalities grows together with the decrease in the socio-economic status of the countries. This hypothesis is based on the work of Szörfi (2007), who stated that the size of regional inequalities as well as their growth was higher in the least developed countries. 


\section{Results}

In the first part of the analysis we used the point method that revealed the spatial distribution of prosperous and lagging counties (Fig. 1, tab. 4 in the annex) using the integrated indicator socio-economic status arising from five indicators (Fig. 2-6 in the annex). We presumed that the counties in the western parts of the countries would have a higher level of socioeconomic status than the counties nearby the eastern borders. Thus, hypothesis $\mathbf{H} \mathbf{1}$ was confirmed only partially. The most significantly it was confirmed in Slovakia, where the economically strongest counties, Bratislava county (370.o p.) and Trnava county (258.6 p.), are located on the west of the country and, the weakest ones are on the east or the south-east (Banská Bystrica - 177.0 p., Prešov - 187.4 p.). This westeast polarization is strongly reinforced by the eccentric location of the capital city Bratislava on the west. In the Czech Republic, the capital city Prague is centrally located and is slightly oriented to the west. In this area, there are also strong counties such as the Capital City of Prague (370.6 p.), Central Bohemian county (284.7 p.) and Plzeň (281.9 p.). Despite the fact, that economically weaker counties are situated on the northeast (Olomouc, Moravian-Silesian), the westeast gradient is disturbed by Karlovy Vary and Ustí nad Labem counties on the north-west. As to Hungary, economically strong counties create a continuous stretch from the Capital City of Budapest (264.9 p.) to the west (Györ-Moson-Sopron - 296.9 p., KomáromEsztergom - 233.3 p.). In this country, rather northsouth and north-southeast gradient was confirmed with economically weak counties neighbouring Croatia (Baranya - 155.8 p.) and Romania (Békés - 155.2 p., Szabolcs-Szatmár-Bereg - 156.1 p.). The predominant west-east dichotomy can be observed in Croatia, where the counties located to the west of the Capital City of Zagreb county (260.o p.), towards the coast create an economically prosperous part of the country (mainly Zadar county - 218.7 p. and Istria - 213.2 p.) and to the east, there is one lagging behind (Vukovar-Srijem - 147.7 p., Virovitica-Podravina - 149.8 p.). In Serbia, there is a dominant northwest-southeast orientation, where there are prosperous counties such as the Capital City of Beograd county (189.9 p.) and the South Bačka (178.8 p.) on one side, and, on the other side are the economically weakest counties not only in Serbia, but also in all the evaluated countries (Zaječar county - 99.1 p., Rasina - 115.6 p., Bor - 117.3 p.). In Poland, the location of prosperous counties is significantly associated with the counties of big cities such Warszawa (449.4 p.), Wroclaw (387.5 p.), Poznań (381.5 p.), Kraków (359.o p.) and Trójmieski (334.3 p.).
The lagging regions are located in the peripheral areas among them and their highest concentration is observed at the eastern borders (e.g. Chelmsko-Zamojski county - 159.3 p., Przemyski - 171.9 p., Krośnienski - 173.2 p.). Despite this fact, the west-east dichotomy is very weakly identifiable.

\section{Level of Regional Inequalities}

Building on the results of the Gini coefficient and the coefficient of variation (tab. 1) it is evident that the Czech Republic has the lowest level of regional inequalities considering all the indicators. A very low level was found both in the birth rate (IG - 0.029, CV -0.058 ) and in the monthly earnings (0.043; 0.103). Relatively high balance among the Czech counties was confirmed by the GDP per capita in PPP $(0.134 ; 0.376)$ and the unemployment rate (0.153; 0.289), while the highest inequalities were in the dwellings completed (0.195; 0.367). A low level of inequalities was also observed in Serbia, in two indicators it had the second lowest value after the Czech Republic (monthly earnings - 0.050; 0.100 and unemployment rate - 0.184; 0.351 ) and in another two indicators at least in one coefficient (completed dwellings - 0.577 and GDP per capita in PPP - 0.341). The highest inequalities, compared to the other countries, were only in the birth rate (0.078; 0.143). A little higher level of inequalities was observed in its neighbour, Croatia having comparable or only a little higher values than the Czech Republic in two indicators, the GDP per capita in PPP (0.156; 0.334) and the birth rate (0,050; 0,092), and only in case of dwellings completed it had second highest inequalities after Hungary (0.391; 0.812). Only a little higher level of inequalities was in Poland, where only the GDP per capita in PPP showed the second highest level of inequalities after Slovakia (0.195; 0.425). The highest inequalities were proven in Hungary and Slovakia. Both countries showed the highest or the second highest level of inequalities in almost all the indicators (Hungary in three indicators, Slovakia in four).

An overall comparison of the regional inequalities using the individual indicators in the evaluated countries reveals that it was definitely the gross birth rate that had the lowest level of inequalities in all the countries (tab. 1), and so the validity of hypothesis $\mathbf{H}_{2}$ was fully confirmed. Even the validity of another hypothesis $\mathbf{H}_{\mathbf{3}}$ was fully confirmed, because the higher level of inequalities in the unemployment rate than in monthly earnings in all the countries was observed. The most significant difference was in Croatia (difference 4.8-times in IG and 4.3-times in CV) and the lowest was in the Czech Republic (IG - 3.6-times, CV - 2.8-times). 


\begin{tabular}{|c|c|c|c|c|c|c|c|c|c|c|c|}
\hline & $\stackrel{\mathscr{I}}{\underline{I}}$ & $\begin{array}{l}0 \\
\\
\end{array}$ & $\mid \begin{array}{c}m \\
\dot{p}\end{array}$ & $\mid \begin{array}{l}\infty \\
\dot{\sim} \\
\dot{\sim}\end{array}$ & $\stackrel{+}{\stackrel{+}{\sim}}$ & $\bar{\varphi}$ & $\begin{array}{l}\stackrel{\leftrightarrow}{0} \\
\stackrel{1}{r}\end{array}$ & $\mid \begin{array}{l}\infty \\
\underset{\sim}{\sim}\end{array}$ & 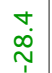 & $\stackrel{\infty}{\Gamma}$ & $\stackrel{\sim}{\sim}$ \\
\hline & $\tilde{\varkappa}$ & Бூధ & $\begin{array}{l}\stackrel{n}{p} \\
\tilde{r}\end{array}$ & $\begin{array}{l}\stackrel{\sim}{\underset{\sim}{\sim}} \\
\mid\end{array}$ & $\begin{array}{l}\stackrel{\circ}{0} \\
\dot{m}\end{array}$ & $\stackrel{\leftrightarrow}{r}$ & $\begin{array}{l}\mathscr{2} \\
0\end{array}$ & $\stackrel{m}{\stackrel{m}{r}}$ & $\begin{array}{l}\infty \\
\underset{\sim}{\sim} \\
\sim\end{array}$ & $\stackrel{\circ}{\circ}$ & $\stackrel{\circ}{\circ}$ \\
\hline$\frac{Ð}{\circ}$ & 亲 & $\begin{array}{l}\hat{\sigma} \\
\hat{\sigma}\end{array}$ & $\begin{array}{l}0 \\
\infty \\
1\end{array}$ & $\mid \begin{array}{l}0 \\
\dot{j} \\
\dot{t}\end{array}$ & $\underset{\sim}{\stackrel{n}{\sim}}$ & $\begin{array}{l}0 \\
\dot{+} \\
i\end{array}$ & $\begin{array}{l}\infty \\
\dot{f} \\
\dot{f}\end{array}$ & $\begin{array}{l}\check{0} \\
\dot{0}\end{array}$ & $\begin{array}{l}\mathfrak{r} \\
\hat{\varphi}\end{array}$ & 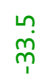 & $\begin{array}{l}\stackrel{\circ}{0} \\
\dot{m}\end{array}$ \\
\hline & $\vec{\alpha}$ & $\stackrel{\stackrel{n}{\tau}}{\tau}$ & $\begin{array}{l}\infty \\
0 \\
0\end{array}$ & $\hat{i}$ & $\stackrel{\circ}{\circ}$ & $\underset{\sim}{\stackrel{\sim}{\sim}}$ & \begin{tabular}{|c}
$\stackrel{n}{\sim}$ \\
\end{tabular} & $\begin{array}{l}\infty \\
\stackrel{0}{0}\end{array}$ & $\bar{\sigma}$ & $\stackrel{m}{\sim}$ & $\stackrel{\sim}{\sim}$ \\
\hline & $\stackrel{\vec{I}}{\mathrm{I}}$ & $\stackrel{\leftrightarrow}{r}$ & $\stackrel{\stackrel{\sim}{i}}{ }$ & $\underset{\dot{\sim}}{\stackrel{\sim}{\sim}}$ & $\begin{array}{l}0 \\
\dot{\sim} \\
\dot{\sim}\end{array}$ & $\stackrel{\leftrightarrow}{\leftarrow}$ & $\stackrel{m}{r}$ & $\mid \begin{array}{l}\tilde{N} \\
\dot{\sim}\end{array}$ & $\stackrel{a}{\dot{p}}$ & $\stackrel{\sim}{\sim}$ & $\stackrel{\text { ก }}{\sim}$ \\
\hline & $N$ & $\stackrel{\stackrel{N}{r}}{\stackrel{r}{r}}$ & $\begin{array}{l}\stackrel{N}{\sim} \\
\Gamma\end{array}$ & $\left|\begin{array}{l}n \\
0 \\
y\end{array}\right|$ & $\begin{array}{l}m \\
\stackrel{0}{n} \\
\stackrel{n}{n}\end{array}$ & นึ. & $\begin{array}{l}\sim \\
\stackrel{n}{n}\end{array}$ & {$\left[\begin{array}{c}n \\
\infty \\
\llcorner\end{array}\right.$} & $\begin{array}{l}0 \\
\underset{N}{N}\end{array}$ & ?ִ & $\underset{\sim}{\sim}$ \\
\hline \multirow{6}{*}{ 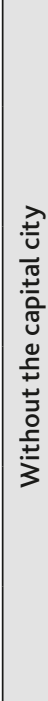 } & $\stackrel{\propto}{I}$ & $\begin{array}{l}\hat{y} \\
\text { o }\end{array}$ & $\begin{array}{l}\infty \\
\infty \\
0 \\
0 \\
0\end{array}$ & $\begin{array}{l}m \\
0 \\
0\end{array}$ & $\begin{array}{l}\infty \\
0 \\
0 \\
0\end{array}$ & $\begin{array}{l}\infty \\
\mathfrak{d} \\
0\end{array}$ & $\mid \begin{array}{c}J \\
⿱ \\
\vdots \\
0\end{array}$ & 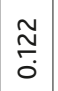 & 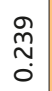 & $\begin{array}{c}\infty \\
\stackrel{\infty}{m} \\
0\end{array}$ & $\begin{array}{l}0 \\
1 \\
\infty \\
0 \\
0\end{array}$ \\
\hline & $\tilde{\varkappa}$ & $\begin{array}{l}\stackrel{+}{0} \\
0 \\
0\end{array}$ & $\begin{array}{l}\infty \\
\stackrel{m}{0}\end{array}$ & $\begin{array}{l}0 \\
\hat{o} \\
0 \\
0\end{array}$ & $\begin{array}{l}0 \\
0 \\
0 \\
0\end{array}$ & $\frac{\infty}{0}$ & 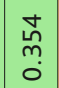 & 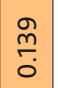 & $\begin{array}{c}\stackrel{\leftrightarrow}{0} \\
\stackrel{0}{0}\end{array}$ & 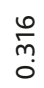 & $\begin{array}{l}m \\
\text { on } \\
o\end{array}$ \\
\hline & 幺̆ & $\begin{array}{l}\bar{\varnothing} \\
0 \\
0\end{array}$ & $\begin{array}{l}\infty \\
\stackrel{\infty}{5} \\
\end{array}$ & $\begin{array}{l}0 \\
\tilde{o} \\
0 \\
0\end{array}$ & $\begin{array}{l}0 \\
0 \\
0\end{array}$ & $\mid \begin{array}{c}n \\
\stackrel{0}{0} \\
0\end{array}$ & $\begin{array}{c}\hat{n} \\
i \mathfrak{o}\end{array}$ & $\begin{array}{l}0 \\
\infty \\
0 \\
0 \\
0\end{array}$ & 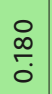 & $\stackrel{\circ}{\stackrel{0}{0}}$ & \begin{tabular}{l} 
fo \\
\multirow{0}{0}{}
\end{tabular} \\
\hline & $\vec{a}$ & $\begin{array}{l}0 \\
\varnothing \\
0 \\
0\end{array}$ & 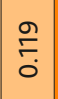 & $\mid \begin{array}{l}0 \\
0 \\
0 \\
0\end{array}$ & $\frac{m}{c}$ & $\begin{array}{l}\stackrel{\sim}{\sim} \\
\stackrel{0}{0}\end{array}$ & 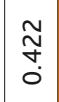 & 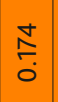 & $\begin{array}{l}\stackrel{+}{*} \\
m \\
0\end{array}$ & $\begin{array}{l}\stackrel{0}{0} \\
\stackrel{0}{0}\end{array}$ & $\begin{array}{l}\tilde{\sigma} \\
0 \\
0\end{array}$ \\
\hline & 고 & $\begin{array}{l}\text { 苟 } \\
0 \\
0\end{array}$ & $\frac{\circ}{\circ}$ & $\begin{array}{l}0 \\
2 \\
0 \\
0\end{array}$ & $\begin{array}{c}\tilde{O} \\
\vdots \\
0\end{array}$ & $\mid \begin{array}{c}0 \\
\infty \\
\sim \\
0 \\
0\end{array}$ & 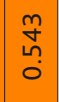 & $\stackrel{\infty}{m}$ & \begin{tabular}{l}
\multirow{N}{N}{} \\
0 \\
0
\end{tabular} & $\begin{array}{l}0 \\
\frac{\sigma}{0} \\
0\end{array}$ & $\begin{array}{c}\infty \\
\infty \\
\infty \\
0\end{array}$ \\
\hline & $N$ & $\begin{array}{l}\tilde{\Xi} \\
0 \\
0\end{array}$ & \begin{tabular}{l}
$\infty$ \\
\multirow{0}{0}{} \\
0
\end{tabular} & $\begin{array}{l}\tilde{\tilde{O}} \\
0 \\
0\end{array}$ & $\begin{array}{l}\text { そ⿱ } \\
0 \\
0\end{array}$ & $\frac{\text { fo }}{\dot{0}}$ & 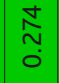 & $\begin{array}{l}\stackrel{L}{ } \\
0 \\
0 \\
0\end{array}$ & $\frac{m}{o}$ & $\frac{⿱}{\circ}$ & $\begin{array}{l}\hat{n} \\
\hat{m} \\
o\end{array}$ \\
\hline \multirow{6}{*}{ 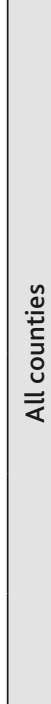 } & $\stackrel{\propto}{\underline{I}}$ & $\begin{array}{l}0 \\
\stackrel{n}{0} \\
0\end{array}$ & $\begin{array}{l}\tilde{\delta} \\
\hat{\delta} \\
0\end{array}$ & $\begin{array}{l}\text { 足 } \\
\hat{O} \\
0\end{array}$ & 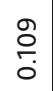 & $\mid \begin{array}{c}0 \\
\stackrel{0}{0} \\
0\end{array}$ & $\begin{array}{c}\tilde{\tilde{f}} \\
\dot{0}\end{array}$ & $\begin{array}{l}\stackrel{0}{L} \\
\stackrel{2}{0}\end{array}$ & $\begin{array}{c}\stackrel{m}{\sim} \\
\stackrel{m}{0}\end{array}$ & $\underset{\substack{\tilde{m} \\
0}}{ }$ & $\begin{array}{l}\tilde{N} \\
\infty \\
0 \\
0\end{array}$ \\
\hline & $\tilde{\varkappa}$ & $\begin{array}{l}\infty \\
0 \\
0 \\
0\end{array}$ & $\frac{m}{\stackrel{m}{0}}$ & $\begin{array}{l}0 \\
\stackrel{n}{0} \\
0\end{array}$ & $\stackrel{\circ}{\circ}$ & $\begin{array}{l}+ \\
\stackrel{\infty}{0} \\
\end{array}$ & $\begin{array}{c}\bar{i} \\
\tilde{n} \\
0\end{array}$ & $\begin{array}{l}\infty \\
\stackrel{0}{0} \\
0\end{array}$ & $\begin{array}{c}\bar{f} \\
m \\
0\end{array}$ & 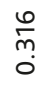 & $\begin{array}{l}\hat{i} \\
\hat{n} \\
0\end{array}$ \\
\hline & $\ddot{n}$ & $\begin{array}{l}0 \\
0 \\
0 \\
0\end{array}$ & $\frac{\text { Ln }}{5}$ & $\begin{array}{l}m \\
\vdots \\
0 \\
0\end{array}$ & $\begin{array}{l}8 \\
\frac{0}{0}\end{array}$ & 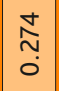 & $\begin{array}{c}m \\
\text { wn } \\
0\end{array}$ & $\begin{array}{l}\underset{N}{N} \\
0\end{array}$ & $\begin{array}{l}0 \\
0 \\
1 \\
0\end{array}$ & $\frac{0}{m}$ & $\begin{array}{l}\text { L } \\
0 \\
0\end{array}$ \\
\hline & $\vec{a}$ & $\begin{array}{l}\hat{o} \\
0 \\
0\end{array}$ & 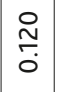 & $\mid \begin{array}{l}n \\
0 \\
0 \\
0\end{array}$ & $\underset{\stackrel{n}{\sim}}{\stackrel{0}{0}}$ & 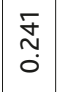 & $\begin{array}{c}m \\
\tilde{q} \\
0\end{array}$ & $\frac{n}{\frac{n}{0}}$ & $\begin{array}{l}\stackrel{\sim}{\sim} \\
\stackrel{\sim}{0}\end{array}$ & $\begin{array}{c}\tilde{N} \\
\tilde{m} \\
0\end{array}$ & $\begin{array}{l}\infty \\
0 \\
0 \\
0\end{array}$ \\
\hline & 고 & $\begin{array}{l}m \\
\hat{\Lambda} \\
0 \\
0\end{array}$ & $\mid \begin{array}{l}\infty \\
0 \\
0 \\
0\end{array}$ & $\begin{array}{l}\tilde{1} \\
0 \\
0\end{array}$ & $\begin{array}{l}\tilde{m} \\
\bar{m} \\
0\end{array}$ & $\mid \begin{array}{c}n \\
\infty \\
\sim \\
0\end{array}$ & $\begin{array}{l}0 \\
\tilde{n} \\
0 \\
0\end{array}$ & $\begin{array}{c}\infty \\
\vdots \\
0\end{array}$ & 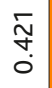 & $\begin{array}{l}0 \\
\frac{\sigma}{\square} \\
0\end{array}$ & $\begin{array}{l}\text { L } \\
\infty \\
0 \\
0\end{array}$ \\
\hline & $N$ & 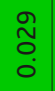 & $\begin{array}{l}\infty \\
\leftrightarrow \\
0 \\
0\end{array}$ & \begin{tabular}{l}
$m$ \\
\multirow{0}{0}{} \\
0
\end{tabular} & 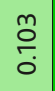 & $\begin{array}{c}n \\
\stackrel{n}{0} \\
\dot{0}\end{array}$ & $\begin{array}{c}0 \\
\stackrel{0}{0} \\
\stackrel{0}{0}\end{array}$ & $\begin{array}{l}\dot{v} \\
\stackrel{m}{0}\end{array}$ & $\begin{array}{l}\stackrel{0}{0} \\
n \\
0\end{array}$ & $\frac{n}{\check{\sigma}}$ & $\begin{array}{l}\hat{0} \\
\tilde{m} \\
0\end{array}$ \\
\hline & & $\underline{\cup}$ & u & $\underline{\cup}$ & u & $\underline{\cup}$ & 己 & $\underline{u}$ & u & $\underline{v}$ & 己 \\
\hline & & & & $\begin{array}{l}\text { 졸 } \\
\text { 辛 } \\
\frac{0}{\Sigma}\end{array}$ & & 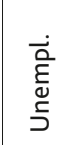 & & $\begin{array}{l}\grave{\vdots} \\
\text { ○े } \\
\text { ò }\end{array}$ & & & 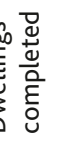 \\
\hline
\end{tabular}

The capital cities of the CEE countries have, as mentioned above, a significant impact on the intensity of regional inequalities, and that is the focus of the following analysis. We observed a decrease in inequalities in all the evaluated countries after excluding the capital city, with regard to the majority of the indicators (tab. 1). The most significant it was in the Czech Republic and Slovakia. The effect of a capital city manifested itself the most in GDP per capita in PPP, where there was a decrease in IG as much as by $58.2 \%(\mathrm{CZ})$ or $60.1 \%$ (SK) and in CV $(72.6 \%, 67.9 \%)$ and in the monthly earnings (IG $-46.5 \%, 46.6 \%$; CV $-56.3 \%, 52.5 \%)$. A slighter decrease of inequalities was also observed in the birth rate (IG - 17.2\%, 19.7\%; CV $-17.2 \%, 18.6 \%$ ), in Slovakia, there was also a more significant decrease in completed dwellings (IG - 33.5\%, $\mathrm{CV}-36.0 \%)$. Therefore, the capitals, Prague and Bratislava, have a significant impact on the level of regional inequalities in these countries and after their exclusion, the Czech Republic even more confirmed its position of a country with the lowest inequalities and Slovakia, a country with the highest inequalities, became a country with the second lowest level. The second group is formed by Hungary, Serbia and Croatia, where there was a perceptible decrease of inequalities after excluding Budapest, Beograd and Zagreb in two indicators on a comparable level: GDP per capita in PPP (IG - 26.2\% HU, 17.3\% RS, 21.8\% HR; CV - 34.9\%, $23.8 \%, 28.4 \%$ ) and monthly earnings (IG $-21.1 \% \mathrm{HU}$, $22.0 \%$ RS, $21.8 \%$ HR; CV $-26.6 \%$, 30.0\%, 28.4\%). As for the remaining indicators, the difference was only up to $6.1 \%$. The given findings show a lower impact of these capital cities on regional inequalities than in the case of Prague and Bratislava. Hungary remained, even after the exclusion of the capital, a country with high inequalities, in Serbia and Croatia no notable change was monitored and remained in the position of the countries with the medium level of inequalities. The lowest decrease of inequalities was noticed in Poland where, after the exclusion of Warszawa, the decrease was max. by $10.8 \%$ (IG) and $19.1 \%(\mathrm{CV})$ in GDP per capita in PPP. Concerning the rest of the indicators, the change was up to $9.6 \%$. In comparison, it would mean that Poland was one of the countries with the highest inequalities in as many as three indicators (GDP per capita in PPP, monthly earnings, birth rate). In this case, the strong influence of the polycentric structure of settlements in Poland with numerous big cities as well as the size of the country itself was confirmed. Now, we can affirm only limited validity of hypothesis $\mathbf{H}_{4}$, while the dominant effect of the influence of a capital city was confirmed notably in the economic indicators such as GDP per capita in PPP and monthly earnings and in the case of the countries, it was in the Czech Republic and Slovakia. 
Table 2. Socio-economic status (points) in V4 countries, Serbia and Croatia

\begin{tabular}{|c|c|c|c|c|c|c|c|c|c|c|c|}
\hline & \multicolumn{2}{|c|}{ Birth rate (\%) } & \multicolumn{2}{c|}{ Month. earnings $(€)$} & \multicolumn{2}{c|}{ Unempl. rate (\%) } & \multicolumn{2}{c|}{ GDP per capita in PPP $(€)$} & \multicolumn{2}{c|}{ Dwellings compl. } & SES (points) \\
\hline CZ & 10.73 & 100.0 & 1313 & 100.0 & 3.07 & 100.0 & 25642 & 100.0 & 3.19 & 66.1 & 466.1 \\
\hline HU & 9.19 & 85.6 & 1035 & 78.8 & 3.71 & 82.7 & 19572 & 76.3 & 1.81 & 37.6 & 361.0 \\
\hline PL & 10.11 & 94.2 & 1135 & 86.4 & 5.80 & 52.9 & 19965 & 77.8 & 4.82 & 100.0 & 411.3 \\
\hline SK & 10.59 & 98.6 & 1013 & 77.2 & 5.04 & 60.9 & 21245 & 82.8 & 3.50 & 72.6 & 392.1 \\
\hline RS & 9.16 & 85.4 & 582 & 44.3 & 12.70 & 24.2 & 11310 & 44.1 & 2.59 & 53.7 & 251.7 \\
\hline HR & 9.04 & 84.2 & 1113 & 84.7 & 11.10 & 27.7 & 17799 & 69.4 & 2.48 & 51.5 & 317.5 \\
\hline
\end{tabular}

Source: own elaboration, Note: CZ - Czech Republic, HU - Hungary, PL - Poland, SK - Slovakia, RS - Serbia, HR - Croatia; SES - Socioeconomic status

The last step was to evaluate the level of dependence between socio-economic status and the level of their regional inequalities using five monitored indicators (tab. 1). The highest level of socio-economic status was observed in the Czech Republic (466.1 p.), the next were Poland (411.3 p.) and Slovakia (392.1 p.), followed by Hungary (361.o p.), Croatia (317.5 p.) and the lowest level was noticed in Serbia (251.7 p.) (tab. 2). level of socio-economic status rose. The suitability of the regression model was not confirmed despite moderate high correlation. Therefore, hypothesis $\mathbf{H}_{5}$ was neither accepted nor refuted with regard to the suitability of the model.

The level of dependence predominantly increased after excluding the capital cities. In general, we can state that no significant correlation dependence be-

Table 3. Rate of dependence between socio-economic status of the countries and their regional inequalities

\begin{tabular}{|l|c|c|c|c|c|}
\hline \multirow{2}{*}{\multicolumn{2}{|c|}{}} & \multicolumn{2}{c|}{ All counties } & \multicolumn{2}{c|}{ Without the capital city } \\
\cline { 3 - 6 } & & R & R2 & R & R2 \\
\hline \multirow{2}{*}{ Gross birth rate } & IG & -0.5580 & 0.3114 & -0.6404 & 0.4101 \\
\cline { 2 - 6 } & CV & -0.5315 & 0.2825 & -0.6461 & 0.4174 \\
\hline \multirow{2}{*}{$\begin{array}{l}\text { Average monthly gross } \\
\text { earnings }\end{array}$} & IG & 0.0438 & 0.0019 & -0.2173 & 0.0472 \\
\cline { 2 - 6 } & CV & 0.2596 & 0.0674 & -0.1084 & 0.0117 \\
\hline \multirow{3}{*}{ Unemployment rate } & IG & -0.1370 & 0.0188 & -0.1860 & 0.0346 \\
\cline { 2 - 6 } & CV & -0.1202 & 0.0144 & -0.1652 & 0.0273 \\
\hline \multirow{2}{*}{ GDP per capita in PPP } & IG & -0.0244 & 0.0006 & -0.4558 & 0.2078 \\
\cline { 2 - 6 } & CV & 0.4078 & 0.1663 & -0.4151 & 0.1723 \\
\hline $\begin{array}{l}\text { Dwellings completed per } \\
\text { 1000 inhabitants }\end{array}$ & IG & -0.5889 & 0.3468 & -0.5947 & 0.3537 \\
\cline { 2 - 6 } & CV & -0.4248 & 0.1804 & -0.4801 & 0.2305 \\
\hline
\end{tabular}

Source: own elaboration

The measure of dependence between the socio-economic status of the countries and the level of their regional inequalities was investigated using the Pearson correlation coefficient $\mathrm{R}$ that was calculated for all the counties in the countries both including and excluding their capitals. The obtained data (tab. 3) prove that the inequalities in the monthly earnings, the unemployment rate and the GDP per capita in PPP (for all the counties) almost do not correlate with the level of socio-economic status of the countries and the linear regression model for their territorial expression is not suitable. In all three indicators, there were values very close to zero, which implies that $\mathbf{H}_{\mathbf{5}}$ was not confirmed.

The inequalities noticed in the birth rate were increasing along with the decreasing level of socioeconomic status. It was likely in dwellings completed where, along with the decrease of inequalities, the tween the socio-economic status and inequalities in monthly earnings and the unemployment rate was proven. The inequalities in the birth rate, the GDP per capita in PPP and dwellings completed negatively correlated with the level of socio-economic status. The highest levels of correlation were observed in the regional inequalities in the birth rate, where the absolute value of the Pearson correlation coefficient $\mathrm{R}$ exceeded 0.64. Despite higher values of $\mathrm{R}$, even in this case it is not possible to accept hypothesis $\mathrm{H}_{5}$ and pronounce a definite conclusion about at least a part of the evaluated indicators, because even in relatively high correlation, the model was not suitable for the use. The decreasing character of the regression line in all the indicators (in case of exclusion of the capitals) implies that the level of inequalities grows together with the decrease of socio-economic status. 


\section{Discussion}

The country with the lowest regional inequalities is the Czech Republic and that was confirmed by all the indicators. By contrast, Hungary and Slovakia showed the highest level. Poland presented a medium level of differences. Similar conclusions were published by Smętkowski (2014), who also confirmed the lowest level of inequalities in the Czech Republic; Poland and Hungary were the countries with a medium level of inequalities and Slovakia was the one with the most significant differences and polarization thanks to fast growth of Bratislava. The named author also pointed out to the size of inequalities after the exclusion of the capital cities where there was the most notable decrease of inequalities in Slovakia and lower in Poland thanks to its polycentric system of settlement. Similarly, some other works such as by Lackenbauer (2006), Monastiriotis (2013), Matlovič et al. (2018), Marošević and Sekur (2018) indicated the importance of a capital city from the point of inequalities within the meaning of their decrease after excluding the capital city.

According to Lackenbauer (2006) inspired by works of Gorzelak (1996) and Enyedi (1996), the fact that metropolitan regions of their capital cities (except from Poland) are a part of a so-called 'Central European boomerang' creating the most advanced part of the CEE countries, has a vast influence on the level of regional inequalities in the $\mathrm{V}_{4}$ countries. It is the axis of GdanskPoznań-Wroclaw-Praha-Brno-Bratislava-ViennaGyör-Budapest that integrates the economically most advanced counties of the V4 countries. Even a so-called 'Central European eastern wall', whose regions (the easternmost regions of Poland, Slovakia and Hungary) are typical for slower growth, poorer education level, infrastructure, foreign capital as well as underdevelopment of neighbouring countries (Belarus, Ukraine, Romania) confirms the identified west-east dichotomy.

Uniformly, Matlovič et al. (2018) identified the existing west-east dichotomy mentioned in the submitted paper (hypothesis $\mathrm{H}_{1}$ ) also via west-east gradient when evaluating the $\mathrm{V}_{4}$ countries. It was the most notable in Slovakia, less in the Czech Republic and Hungary and least strong in Poland. This decrease in economic status was similarly mentioned by Blažek and
Csank (2005), Lang (2015), Kebza et al. (2015), Klamár (2016) and Kubeš and Kebza (2018).

In the case of Serbia and Croatia, the second and third lowest level of inequalities were demonstrated, even after the exclusion of their capitals, their level remained medium. In the case of Serbia, their lower level of inequalities is rather surprising, because a number of authors such as Mijačić and Paunović (2011), Lukić and Stoilković (2017) drew attention to their high rate compared to the other EU countries. The identified inequalities have their grounds in decreased economic efficiency in the northwestern-southeastern direction (in all the indicators), which is consistent with the works by Mijačić and Paunović (2011), Jakopin (2014) and Joksimović and Golić (2017). This originated in the late transformation process in the country (Winkler, 2012), unfavourable demographic trends, small scale industrial production, high unemployment rate and inadequate infrastructure (Joksimović \& Golić, 2017) which manifested itself in the higher poverty risk rate in Europe (24.3\%) as well as in the low Competitiveness Index Europe 2020 (Jakopin, 2014).

Croatia had a little higher level of inequalities, however, in the GDP per capita in PPP and the birth rate it had the second lowest inequalities after the Czech Republic. Đokić et al. (2015) state that Croatia is a remarkably heterogeneous country with high regional inequalities in economic and social development, while they refer to the works of Puljiz and Maleković (2007), who identified significant inequalities in the unemployment rate and slightly from the point of income (these differences also affirmed the results of the submitted paper - hypothesis $\mathrm{H}_{3}$ ). In compliance with the work by Marošević and Sekur (2018), we also identified the strong position of the capital, Zagreb, from the point of inequalities, however not that significant as in the case of Prague or Bratislava (tab. 1). The identified inequalities arise from the fact that economically prosperous counties are located to the west from Zagreb, to the coast and along it. To the east in direction to the borders with Serbia are concentrated those underdeveloped ones (apart from the birth rate, it was confirmed in all the indicators).

\section{Conclusion}

In the overall evaluation of regional inequalities, it is evident that the lowest level was proven in the Czech Republic that also had the highest level of socio-economic status. The second highest inequalities were found in Serbia followed by Croatia, despite the fact they had the lowest or the second lowest level of socio-economic status. To the contrary, the highest inequalities were demonstrated in Slovakia and Hungary. From the point of individual indicators, the univocally lowest values of inequalities were observed in the 
gross birth rate as the only non-economic indicator. Almost in all the evaluated countries (apart from Poland - polycentric character of settlement) a strong influence of their capital cities was found regarding the level of inequalities, the most significant cases being Prague and Bratislava. After their exclusion, the inequalities in Slovakia even decreased to the second lowest level after the Czech Republic. The identified inequalities in the evaluated countries are to a large extent influenced by the dichotomy between prosperous west and problematic east and that was most notable in Slovakia; it was also proven in the Czech Republic and Croatia, in Hungary it was rather northsouthern and north-southeastern direction and in Serbia in a northwestern-southeastern direction. In Poland, its polycentric settlement and the presence of more big cities did not make the development in the west-east direction possible, however, less developed counties were more concentrated at the eastern border. The described facts also had an impact also on the evaluation of the dependence between the socio-economic status of the countries and their regional inequalities. The decreasing character of the regression line and relatively strong correlation in the indicators - the birth rate and dwellings completed - in both cases, and in inequalities in GDP per capita in PPP after excluding the capitals, pointed out to the fact that the level of inequalities decreases together with growing socio-economic status. A definite confirmation of the hypothesis could not be stated regarding the suitability of the model. In other inequality rates, the hypothesis was not confirmed.

\section{Acknowledgements}

This study was supported by scientific projects VEGA 1/0299/19, VEGA 1/o059/19 and APVV-15-0406.

\section{References}

Ancuţa, C. (2012). Aspects regarding the socio-economic indicators used in approaching the territorial disparities. Geographica Pannonica, 16(1), 26-34.

Blažek, J., \& Csank, P. (2005). The West-East gradient and regional development: the case of the Czech Republic. AUC Geographica, 40(1-2), 89-108.

Blažek, J., \& Csank, P. (2007). Nová fáze regionálního rozvoje v ČR? [A new phase of regional development in the Czech Republic?]. Sociologický časopis, 43(5), 945-965 (in Czech).

Bogumił, P. (2009). Regional disparities in Poland. ECFIN Country Focus, 6(4), 1-7.

Czyż, T., \& Hauke, J. (2011). Evolution of regional disparities in Poland. Quaestiones Geographicae, 30(2), 35-48, DOI: 10.2478/v10117-011-0016-y.

Domański, B. (2011). Post-socialism and transition. In A. Pike, A. Rodríguez-Pose, \& J. Tomaney (Eds.), Handbook of local and regional development (pp. 172-181). New York: Routledge.

Đokić, I., Fröhlich, Z., \& Rašić Bakarić, I. (2015). The impact of the economic crisis on regional disparities in Croatia. Cambridge Journal of Regions, Economy and Society, 9(1), 179-195, DOI:10.1093/cjres/ rsvo3o.

Enyedi, G. (1996). New Regional Processes in Post-Socialist Central Europe. In F.W Carter, P. Jordan \& V. Rey (Eds.), Central Europe after the Fall of the Iron Curtain: Geopolitical Perspectives, Spatial Patterns and Trends (pp. 129-136), Frankfurt am Main: Peter Lang.
Fecková Škrabuláková, E., Grešová, E., \& Khouri, S. (2019). Similarity assessment of economic indicators of selected countries by graph theory means. Transformation in Business \& Economic, $18\left({ }_{3} \mathrm{C}\right.$ (48C)), 333-347.

Gorzelak, G. (1996). The Regional Dimension of Transformation in Central Europe. London: Jessica Kingsley Publishers and Regional Studies Association.

Gregorová, G. \& Fillová, V. (2004). Štatistické metódy $\mathrm{v}$ geografii. [Statistical methods in geography]. Bratislava: Geografika (in Slovak).

Gurgul, H., \& Lach, Ł. (2011). The impact of regional disparities on economic growth. MPRA paper No. 52258, Available at: https://mpra.ub.uni-muenchen. de/52258/ (20.12.2019).

Hučka, M., Kutcherauer, A., \& Tománek, P. (2008). Metodologická východiska zkoumání regionálních disparit [Methodological bases of regional disparities]. Working papers N.2, Ostrava: Ekonomická fakulta, VŠB TU (in Czech).

Chajdiak, J. (2009). Štatistika v exceli 2007. [Statistics in Excel 2007]. Bratislava: Statis (in Slovak).

Illieva, M. (2015). Regional disparities in Poland and Bulgaria. Geography and Tourism, 3(2), 35-48, DOI: 10.5281/zenodo.46677.

Ivančev, O., Jovičić, M., \& Milojević, T. (2010). Income Inequality and Social Policy in Serbia. Working $\mathrm{Pa}$ pers, o86, 1-49. 
Jakopin, E. (2014). Regional inequalities and transition: The case of Serbia. Ekonomika preduzeća, 62(1-2), 117-133, DOI:10.5937/ekopre1402117I.

Joksimović, M., \& Golić, R. (2017). Indicators of regional inequality in Serbia. Collection of Papers Faculty of Geography at the University of Belgrade, 65(1a), 227-249, DOI: 10.5937/zrgfub1765227J.

Kebza, M., Kubeš, J., \& Nováček, A. (2015). Východozápadní gradient sociální a ekonomické prostorové diferenciace Madarska [East-west gradient of social and economic space differentiation in Hungary]. In V. Klímová \& V. Žitek, V. Proceedings of the 18th International colloquium on regional sciences (pp. 41-48), Hustopeče, Czech Republic, DOI: 10.5817/ CZ.MUNI.P210-7861-2015-4 (in Czech).

Kisiała, W., \& Suszyńska, K. (2017). The dynamics of regional inequalities and economic growth in Central and Eastern Europe. Institute of Economic Research Working Papers, 122, $10 \mathrm{p}$.

Klamár, R. (2016). Development tendencies of regional disparities in the Slovak Republic. Geographica Pannonica, 2O(3), 136-151, DOI: 10.18421/GP20.03-02.

Klamár, R., Matlovič, R., Ivanová, M., Ištok, R., \& Kozoň, J. (2019a): Local Action Group as a Tool of Inter-municipal Cooperation: Case Study of Slovakia. Folia Geographica, 61(1), 36-67.

Klamár, R., Rosič, M., Madziková, A., Krokusová, J., Pasternák, T., \& Kozoň, J. (2019b). Regionálny rozvoj-faktory, disparity a cezhraničná spolupráca. [Regional development - factors, inequalities and cross-border cooperation]. Prešov: Prešovská univerzita (in Slovak).

Kubeš, J., \& Kebza, M. (2018). Geography of socio-economic differentation of Poland according to subregions in 2002-2014. AUC Geographica, 53(1), 36-48, https://doi.org/10.14712/23361980.2018.4.

Kutscherauer, A., Fachinelli, H., Hučka, M., Skokan, K., Sucháček, K., Tománek, J., \& Tuleja, P. (2010). Regional disparities. Disparities in country regional development - concept, theory, identification and assessment. Available at: http://alkut.cz/edice $\mathrm{cd} / \mathrm{cd} 11 \mathrm{regdis}$ mono angl/pdf/Regional\%20disparities.pdf (15.10.2019).

Kutscherauer, A., \& Hučka, M. (2011). Teoreticko-metodické otázky regionálních disparit [Theoretical and methodological questions of regional disparities]. Regionální disparity, 9, 20-30 (in Czech).

Lackenbauer, J. (2004). Catching-up, Regional Disparities and EU Cohesion Policy: The case of Hungary. Managing Global Transition, 2(2), 123-162.

Lackenbauer, J. (2006). After Transition and EU Accession: A Review of Economic Geography and Regional Disparities in Hungary. Available at: http:// www.wz.uni.lodz.pl/ersa/abstr/lackenbauer p.pdf (15.10.2019).
Lang, T. (2015). Socio-economic and political responses to regional polarisation and socio-spatial peripheralisation in Central and Eastern Europe: a research agenda. Hungarian Geographical Bulletin, 64(3), 171-185, DOI: 10.15201/hungeobull.64.3.2.

Lukić, V., \& Stoilković, M.A. (2017). Interrelation of spatial disparities in development and migration patterns in transition economy: Serbia - Case study. Human Geographies - Journal of Studies and Research in Human Geography, 11(1), 65-76, DOI: 10.5719/hgeo.2017.111.4.

Majerová, I. (2012). International development cooperation of the Czech Republic in the context of European development. Prague economic papers, 21, 166-185.

Marošević, K., \& Sekur, T. (2018). Comparative Analysis of Croatian and Czech Lagging Regions. European Scientific Journal, ESJ August 2018 Special Edition, 63-74, Doi: 10.19044/esj.2018.c4p5 URL:http:// dx.doi.org/10.19044/esj.2018.c4p5.

Matlovič, R., Klamár, R., Kozoň, J., Ivanová, M., \& Michalko, M. (2018). Spatial polarity and spatial polarization in the context of supranational and national scales: regions of Visegrad countries after their accession to the EU. Bulletin of geography: Socio-economic series, 41(3), 59-78, DOI: 10.2478/bog-2018-0026.

Matlovič, R., \& Matlovičová, K. (2005). Vývoj regionálnych disparít na Slovensku a problémy regionálneho rozvoja Prešovského kraja [Development of regional disparities in Slovakia and problems of regional development in the Prešov region]. Folia Geographica, 8, 66-88 (in Slovak).

Matlovič, R., \& Matlovičová, K. (2011). Regionálne disparity a ich riešenie na Slovensku v rozličných kontextoch [Regional disparities and their solution in Slovakia in the various context]. Folia Geographica, 18, 8-88 (in Slovak).

Michálek, A. (2012). Vybrané metódy merania regionálnych disparít. [Some methods for measuring regional disparities]. Geografický časopis, 64(3), 219-234 (in Slovak).

Mijačić, D., \& Paunović, B. (2011). Regional disparities in Serbia. Ekonomika preduzeća, 59(7-8), 379389, DOI: 10.5937/ekopre1108379M.

Miljanović, D., Miletić, R., \& Đordević, J. (2010). Regional inequality in Serbia as a development problem. Acta geographica Slovenica, 50(2), 253-275, DOI: 10.3986/AGS50204.

Monastiriotis, V. (2013). The Nature of Spatial Inequalities in South East Europe and the Scope for Decentralized Regional Policy: An Analysis of Bulgaria and Serbia. In W. Barlett, S. Maleković, V. Monastiriotis, \& S. Maleković (Eds.), Decentralization and Local Development in South East Europe (pp. 213230). London: Palgrave Macmillan UK. 
Nosek, V., Netrdová, P. (2010). Regional and Spatial Concentration of Socio-economic Phenomena: Empirical Evidence from the Czech Republic. Ekonomický časopis, 58(4), 344-359.

Puljiz, J., \& Maleković, S. (2007). Regional income and unemployment disparities in Croatia. In Z. Reić, M. Fredotović (Eds.), Conference proceedings of the 7 th International Conference: Enterprise in Transition (pp. 1280-1298). Split, Croatia.

Rusnák, J. (2012). Premenlivost' geografických javov v reálnych systémoch. [Variability of geographical phenomena in reality]. AUC Geographica, 56(1), 7997 (in Slovak).
Smętkowski, M. (2014). Regional disparities and development Dynamics of CEE regions in the period of prosperity and austernity. Working Paper Series GRINCOH, 6, 1-19, Warszaw: Centre for European Regional and Local Studies.

Szörfi, B. (2007). Development and regional disparities - testing the Williamson curve hypothesis in the European Union. Focus on European Economic Integration, Oesterreichische Nationalbank (Austrian Central Bank), 2, 100-121.

Winkler, A. (2012). Measuring regional inequality: an index of socio-economic pressure for Serbia. Collection of Papers - Faculty of Geography at University of Belgrade, 60, 81-102.

\section{Annex}

Table 4. List of counties (NUTS 3) and the level of their socio-economic status (points)

\begin{tabular}{|c|c|c|c|c|c|c|c|c|}
\hline \multicolumn{2}{|c|}{ POLAND } & Points & 58 & Włocławski & 168.3 & 112 & Szabolcs-Szatmár-Bereg & 156.1 \\
\hline 1 & City of Łódź & 226.6 & 59 & Elbląski & 185.7 & 113 & Bács-Kiskun & 204.3 \\
\hline 2 & Łódzki & 197.7 & 60 & Olsztyński & 201.3 & 114 & Békés & 155.2 \\
\hline 3 & Piotrkowski & 208.4 & 61 & Ełcki & 170.4 & 115 & Csongrád & 190.4 \\
\hline 4 & Sieradzki & 187.2 & 62 & Stupski & 207.2 & \multicolumn{2}{|c|}{ SERBIA } & Points \\
\hline 5 & Skierniewicki & 189.3 & 63 & Trójmiejski & 334.3 & 116 & Capital City of Beograd & 189.9 \\
\hline 6 & Ciechanowski & 194.4 & 64 & Gdański & 259.7 & 117 & West Bačka & 118.9 \\
\hline 7 & Ostrołęcki & 196.4 & 65 & Starogardzki & 203.7 & 118 & South Banat & 140.5 \\
\hline 8 & Capital City of Warszawa & 449.4 & 66 & Płocki & 230.1 & 119 & South Bačka & 178.8 \\
\hline 9 & Radomski & 188.4 & 67 & Siedlecki & 214.2 & 120 & North Banat & 121.2 \\
\hline 10 & Warszawski-wschodni & 244.6 & 68 & Nowotarski & 198.2 & 121 & North Bačka & 144.1 \\
\hline 11 & Warszawski-zachodni & 301.2 & 69 & Szczecinecko-Pyrzycki & 161.5 & 122 & Central Banat & 135.1 \\
\hline 12 & City of Kraków & 359.0 & 70 & Inowroclawski & 172.9 & 123 & Srem & 142.0 \\
\hline 13 & Krakowski & 236.2 & 71 & Świecki & 188.2 & 124 & Zlatibor & 148.4 \\
\hline 14 & Nowosądecki & 200.9 & 72 & Chojnicki & 200.7 & 125 & Kolubara & 138.8 \\
\hline 15 & Oświęcimski & 192.9 & 73 & Żyrardowski & 224.7 & 126 & Mačva & 131.7 \\
\hline 16 & Tarnowski & 188.2 & \multicolumn{2}{|c|}{ SLOVAK REPUBLIC } & Points & 127 & Moravica & 138.4 \\
\hline 17 & Częstochowski & 190.0 & 74 & Bratislava & 370.0 & 128 & Pomoravlje & 120.9 \\
\hline 18 & Bielski & 230.4 & 75 & Trnava & 258.6 & 129 & Rasina & 115.6 \\
\hline 19 & Rybnicki & 221.6 & 76 & Trenčín & 214.7 & 130 & Raška & 151.2 \\
\hline 20 & Bytomski & 187.4 & 77 & Nitra & 205.2 & 131 & Šumadija & 138.9 \\
\hline 21 & Gliwicki & 232.0 & 78 & Žilina & 219.7 & 132 & Bor & 117.3 \\
\hline 22 & Katowicki & 252.1 & 79 & Banská Bystrica & 177.0 & 133 & Braničevo & 127.9 \\
\hline 23 & Sosnowiecki & 198.7 & 80 & Prešov & 187.4 & 134 & Zaječar & 99.1 \\
\hline 24 & Tyski & 259.4 & 81 & Košice & 195.7 & 135 & Jablanica & 118.0 \\
\hline 25 & Bialski & 184.1 & \multicolumn{2}{|c|}{ CZECH REPUBLIC } & Points & 136 & Nišava & 138.7 \\
\hline 26 & Chetmsko-zamojski & 159.3 & 82 & Capital City of Prague & 370.6 & 137 & Pirot & 119.6 \\
\hline 27 & Lubelski & 235.3 & 83 & Central Bohemian & 284.7 & 138 & Podunavlje & 114.2 \\
\hline 28 & Puławski & 178.7 & 84 & South Bohemian & 255.8 & 139 & Pčinja & 128.9 \\
\hline 29 & Krośnieński & 173.2 & 85 & Plzeň & 281.9 & 140 & Toplica & 120.5 \\
\hline 30 & Przemyski & 171.9 & 86 & Karlovy Vary & 219.9 & 141 & Kosovska Mitrovica & - \\
\hline
\end{tabular}


Regional Inequalities in the Visegrad Group Countries,

Serbia and Croatia

\begin{tabular}{|c|c|c|c|c|c|c|c|c|}
\hline 31 & Rzeszowski & 234.0 & 87 & Ústí nad Labem & 214.7 & 142 & Peć & - \\
\hline 32 & Tarnobrzeski & 190.3 & 88 & Liberec & 242.4 & 143 & Kosovo & - \\
\hline 33 & Kielecki & 184.9 & 89 & Hradec Králové & 260.3 & 144 & Kosovo-Pomoravlje & - \\
\hline 34 & Sandomiersko-Jędrzejowski & 173.8 & 90 & Pardubice & 263.8 & 145 & Prizren & - \\
\hline 35 & Białostocki & 225.6 & 91 & Vysočina & 248.0 & \multicolumn{2}{|c|}{ CROATIA } & Points \\
\hline 36 & Łomżyński & 187.2 & 92 & South Moravian & 261.8 & 146 & Primorje-Gorski kotar & 192.6 \\
\hline 37 & Suwalski & 185.1 & 93 & Olomouc & 237.5 & 147 & Lika-Senj & 185.5 \\
\hline 38 & Pilski & 201.5 & 94 & Zlín & 248.5 & 148 & Zadar & 218.7 \\
\hline 39 & Koniński & 205.2 & 95 & Moravian-Silesian & 225.3 & 149 & Šibenik-Knin & 169.8 \\
\hline 40 & City of Poznań & 381.5 & \multicolumn{2}{|c|}{ HUNGARY } & Points & 150 & Split-Dalmatia & 188.4 \\
\hline 41 & Kaliski & 230.6 & 96 & Capital C. of Budapest & 264.9 & 151 & Istria & 213.2 \\
\hline 42 & Leszczyński & 243.7 & 97 & Pest & 234.8 & 152 & Dubrovnik-Neretva & 202.3 \\
\hline 43 & Poznański & 324.0 & 98 & Fejér & 216.4 & 153 & Capital City of Zagreb & 260.0 \\
\hline 44 & Koszaliński & 217.2 & 99 & Komárom-Esztergom & 233.3 & 154 & Zagreb & 180.5 \\
\hline 45 & City of Szczecin & 269.8 & 100 & Veszprém & 213.4 & 155 & Krapina-Zagorje & 164.5 \\
\hline 46 & Szczeciński & 200.2 & 101 & Győr-Moson-Sopron & 296.9 & 156 & Varaždin & 177.2 \\
\hline 47 & Gorzowski & 205.9 & 102 & Vas & 214.2 & 157 & Koprivnica-Križevci & 173.9 \\
\hline 48 & Zielonogórski & 209.1 & 103 & Zala & 185.4 & 158 & Međimurje & 192.5 \\
\hline 49 & City of Wroctaw & 387.5 & 104 & Baranya & 155.8 & 159 & Bjelovar-Bilogora & 156.9 \\
\hline 50 & Jeleniogórski & 179.1 & 105 & Somogy & 171.1 & 160 & Virovitica-Podravina & 149.8 \\
\hline 51 & Legnicko-Głogowski & 240.3 & 106 & Tolna & 205.3 & 161 & Požega-Slavonia & 154.8 \\
\hline 52 & Wałbrzyski & 170.9 & 107 & Borsod-Abaúj-Zemplén & 184.4 & 162 & Slavonski Brod-Posavina & 152.1 \\
\hline 53 & Wrocławski & 260.3 & 108 & Heves & 205.1 & 163 & Osijek-Baranja & 157.1 \\
\hline 54 & Nyski & 171.0 & 109 & Nógrád & 150.3 & 164 & Vukovar-Srijem & 147.7 \\
\hline 55 & Opolski & 201.3 & 110 & Hajdú-Bihar & 180.8 & 165 & Karlovac & 161.5 \\
\hline 56 & Bydgosko-Toruński & 227.1 & 111 & Jász-Nagykun-Szolnok & 173.3 & 166 & Sisak-Moslavina & 151.6 \\
\hline 57 & Grudziądzki & 186.4 & & & & & & \\
\hline
\end{tabular}

Source: own elaboration, Note: order number of the county serves for its identification in Figures 1-6 


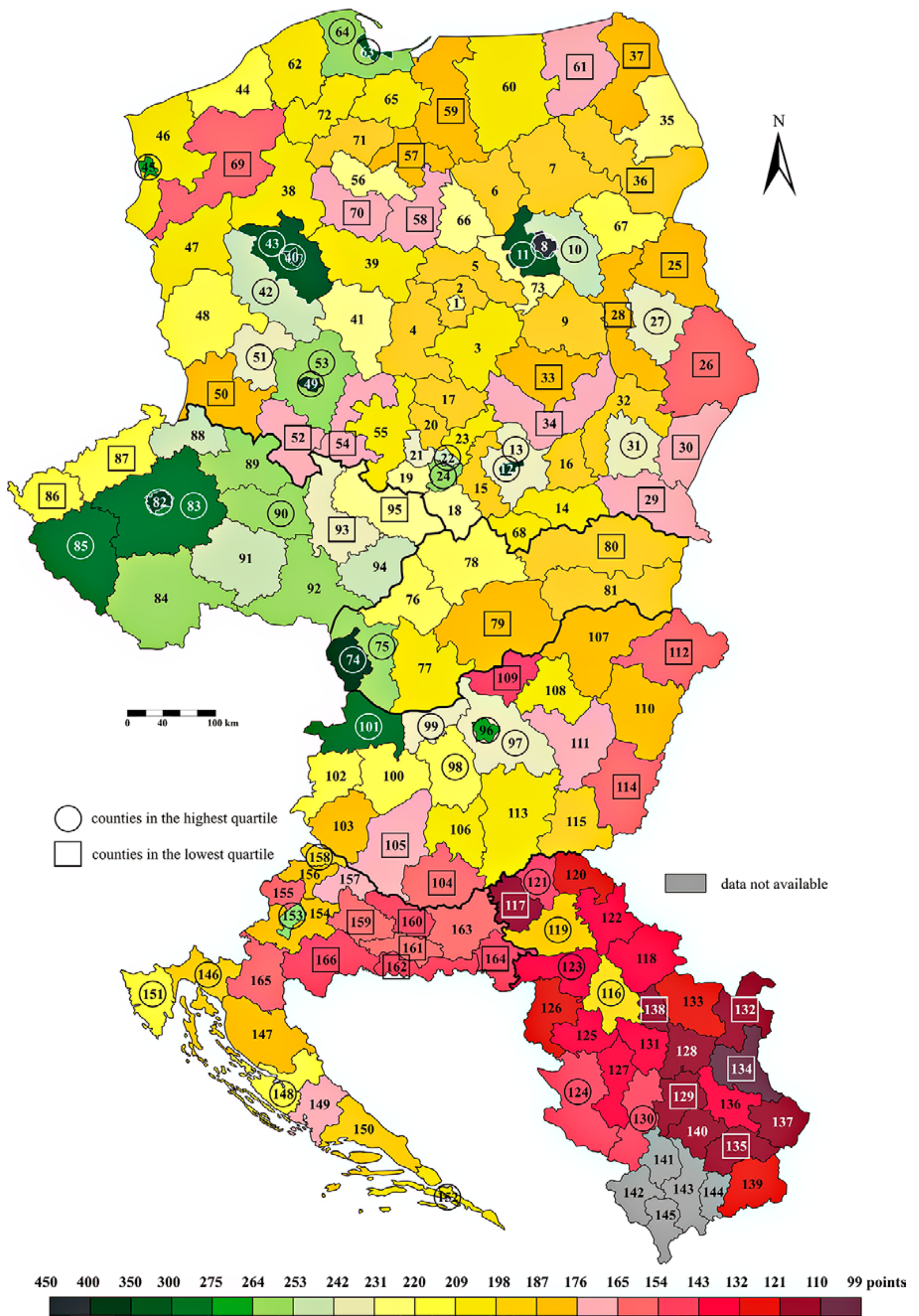

Figure 1. Socio-economic status in counties in V4 countries, Serbia and Croatia (2018) Source: our processing, tab. 4 


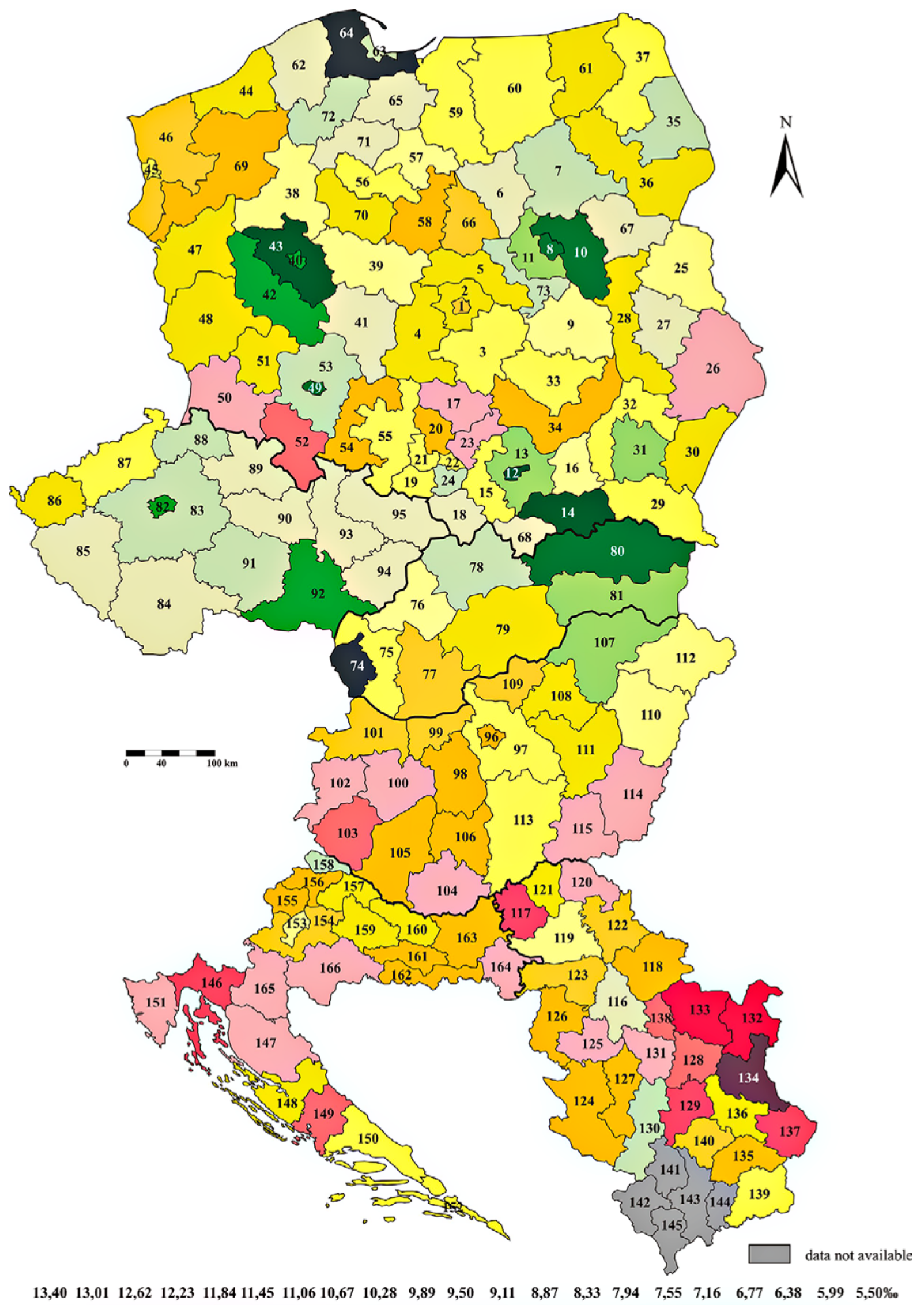

Figure 2. Gross birth rate in counties in V4 countries, Serbia and Croatia (2018)

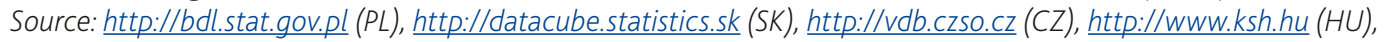
http://data.stat.gov.rs (RS), http://www.dzs.hr (HR) 


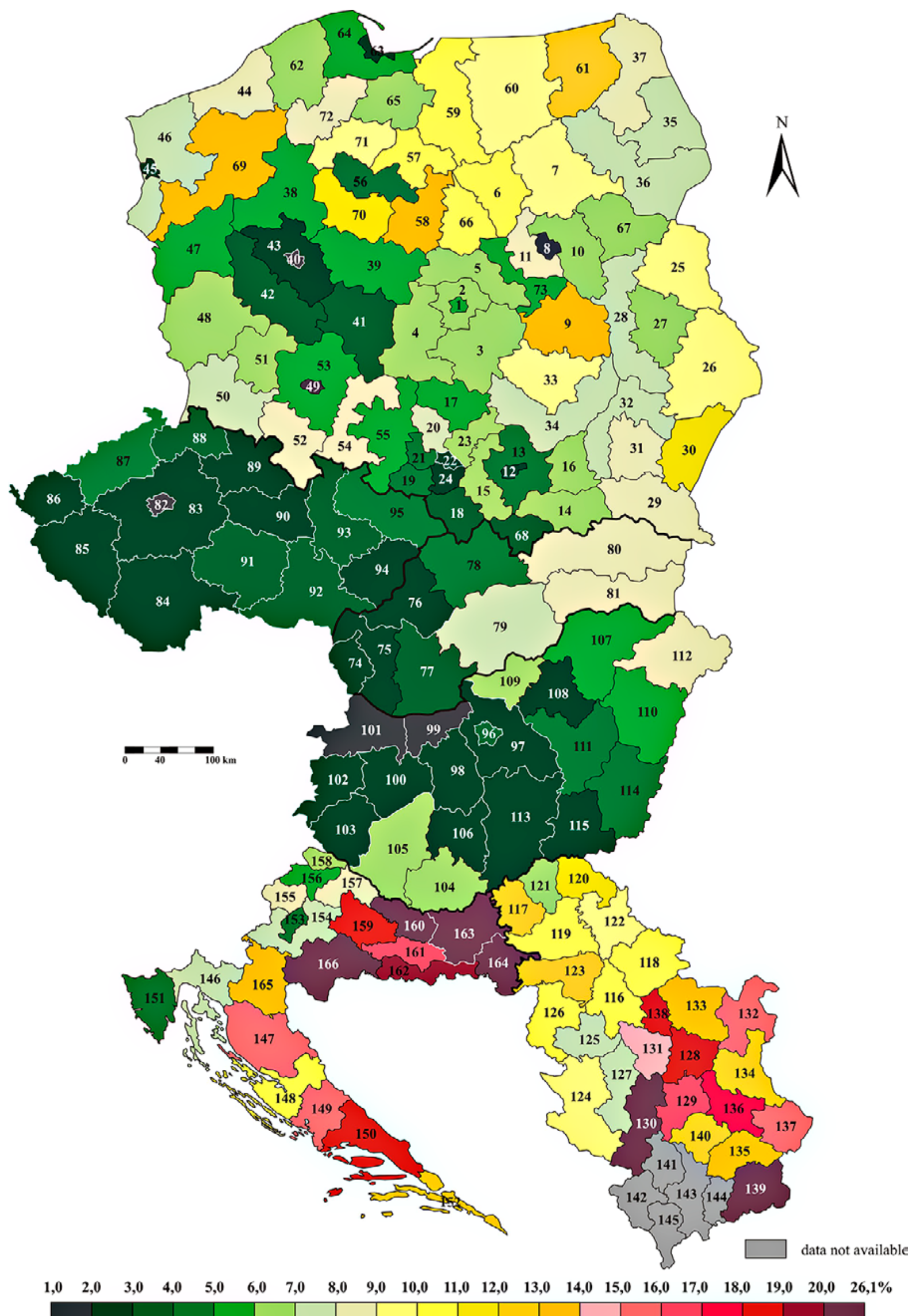

Figure 3. Unemployment rate in counties in V4 countries, Serbia and Croatia (2018) Source: $h t t p: / / b d l . s t a t . g o v . p l(P L)$, http://datacube.statistics.sk (SK), http://vdb.czso.cz (CZ), http://www.ksh.hu (HU), http://data.stat.gov.rs (RS), http://www.dzs.hr (HR) 


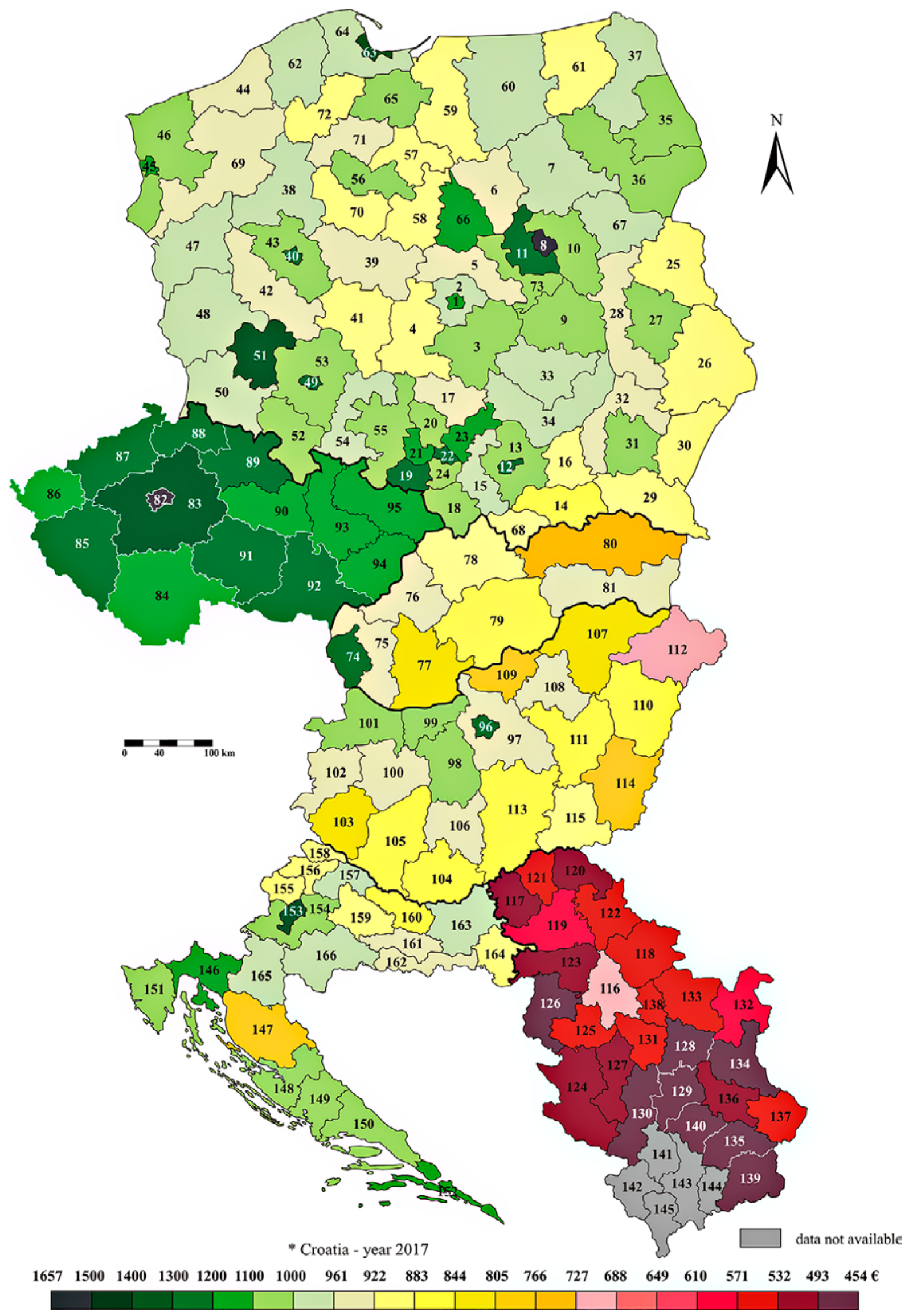

Figure 4. Average monthly gross earnings in counties in V4 countries, Serbia and Croatia (2018)* Source: $h t t p: / / b d l . s t a t . g o v . p l(P L)$, http://datacube.statistics.sk (SK), http://vdb.czso.cz (CZ), http://www.ksh.hu (HU), http://data.stat.gov.rs (RS), http://www.dzs.hr (HR) 


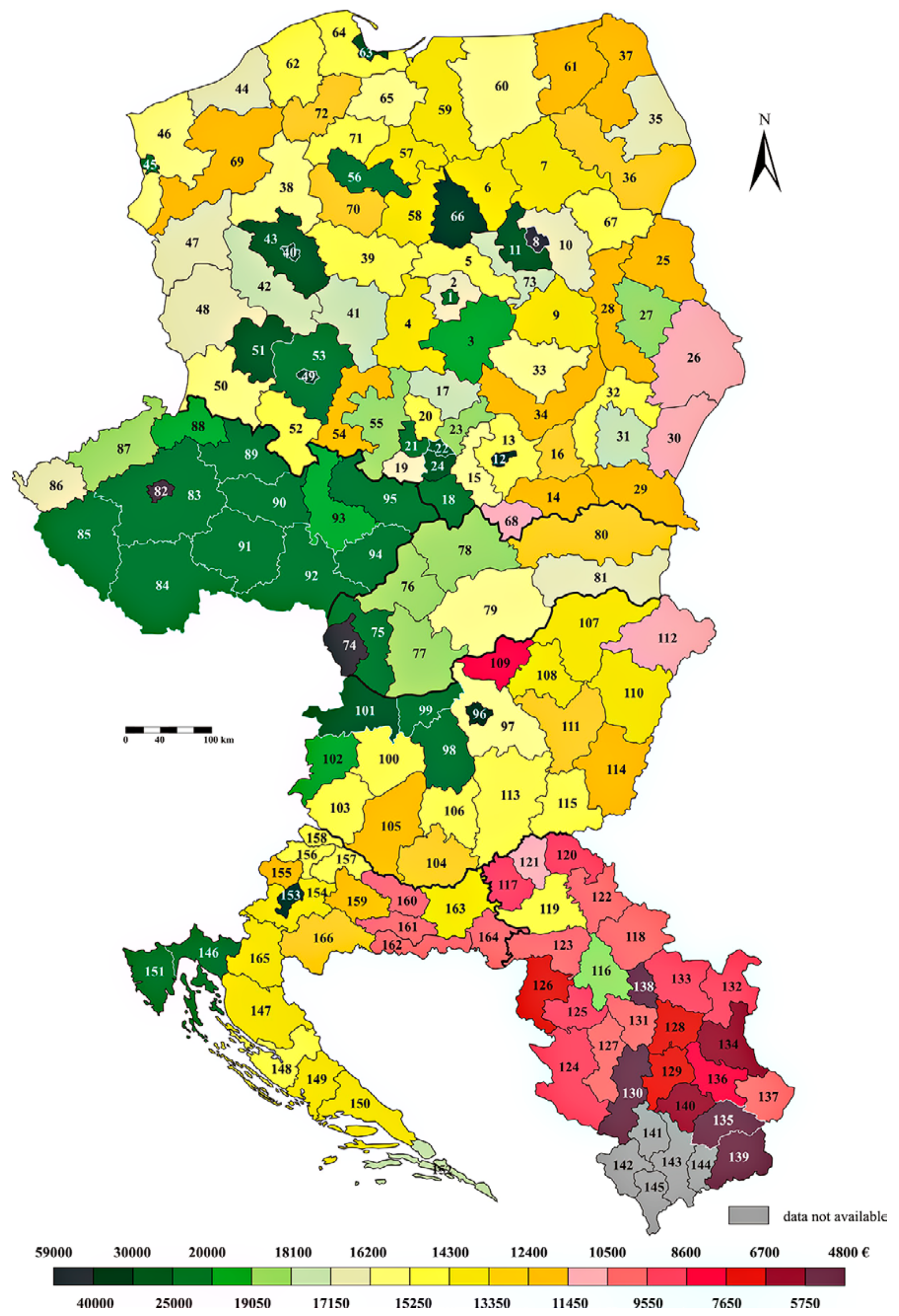

Figure 5. GDP per capita in PPP in counties in V4 countries, Serbia and Croatia (2016)

Source: https://appsso.eurostat.ec.europa.eu/nuilsubmitViewTableAction.do (PL, SK, CZ, HU, RS, HR) 


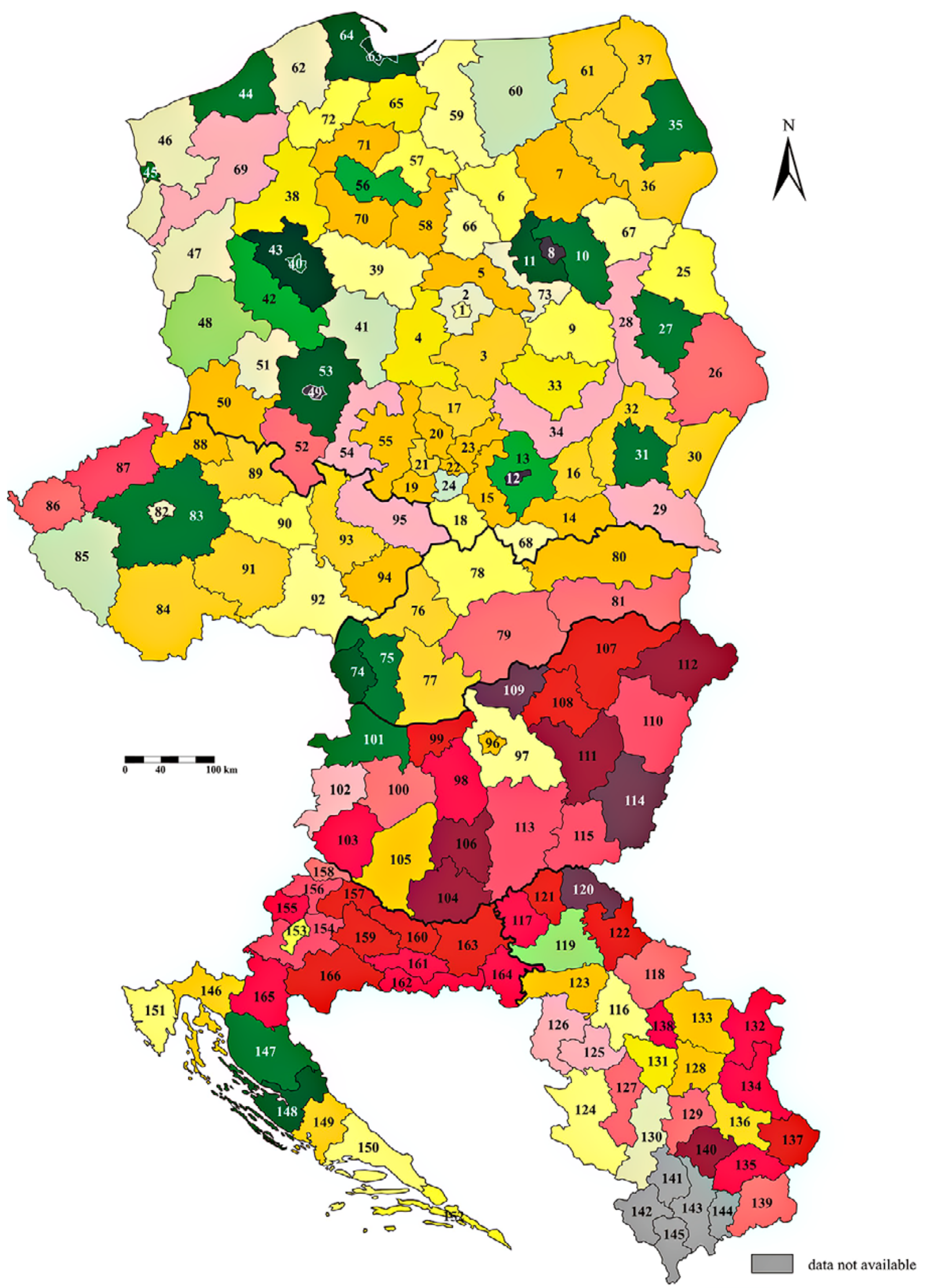

$\begin{array}{lllllllllllllllllllll}15,00 & 12,50 & 10,00 & 7,50 & 5,00 & 4,69 & 4,38 & 4,07 & 3,76 & 3,45 & 3,14 & 2,83 & 2,52 & 2,21 & 1,90 & 1,59 & 1,28 & 0,97 & 0,66 & 0,35 & 0,04 \\ \text { dwellings }\end{array}$

Figure 6. Dwellings completed per 1000 inhabitants in counties in V4 countries, Serbia and Croatia (2018) Source: http://bdl.stat.gov.pl (PL), http://datacube.statistics.sk (SK), http://vdb.czso.cz (CZ), http://www.ksh.hu (HU), http://data.stat.gov.rs (RS), http://www.dzs.hr (HR) 